\title{
Comparative study of salt, total fat and sugar contents of mayonnaise and salad dressings from the Iranian market
}

Khadijeh Khoshtinat, ${ }^{1}$ Paliz Koohy-Kamaly, ${ }^{1}$ Rozita Komeili-Fanood, ${ }^{1}$ Sara Sohrabvandi, ${ }^{1}$ Kianoush Khosravi-Darani, ${ }^{1}$ Mehrdad Mohammadi, ${ }^{1}$ Hadiseh Zand-Rajabi, ${ }^{1}$ Elmira Tavakoli, ${ }^{1}$ Mahdieh Salehi, ${ }^{1}$ Ghazaleh Bahramian ${ }^{1}$ and Zahra Vosoughi ${ }^{2}$

${ }^{1}$ Department of Food Technology Research, Faculty of Nutrition Sciences and Food Technology, National Nutrition and Food Technology Research Institute, Shahid Beheshti University of Medical Sciences, Tehran, Islamic Republic of Iran (Correspondence to: K. Khoshtinat: khosh41@yahoo.com, kh.khoshtinat@sbmu.ac.ir). ${ }^{2}$ Faculty of Petroleum and Chemical Engineering, Science and Research Branch, Islamic Azad University, Tehran, Islamic Republic of Iran.

\begin{abstract}
Background: Dietary intake of fat, salt and sugar is important for prevention of noncommunicable diseases; therefore, evaluation of these constituents in industrial packaged foods is necessary.

Aims: To compare the levels of fat, salt and sugar in mayonnaise and salad dressings commercialized in the Islamic Republic of Iran in 2017 and 2019, and to monitor compliance with standard limits.

Methods: The levels of fat, salt and sugar in 12 mayonnaise and 47 salad dressing samples collected from an Iranian market were evaluated according to the Iranian Institute of Standards and Industrial Research of Iran (ISIRI) and compared between 2017 and 2019.

Results: We determined compliance with ISIRI limits and other standard targets. The salt content of mayonnaise samples significantly decreased from 2.03 (standard deviation; 0.3) g/100 $\mathrm{g}$ in 2017 to $1.61(0.12) \mathrm{g} / 100 \mathrm{~g}$ in $2019(P=0.031)$. Total sugar level of mayonnaise samples significantly decreased from $5.97(1.14) \mathrm{g} / 100 \mathrm{~g}$ in 2017 to 3.63 (0.53) g/100 g in $2019(P=0.005)$. The total sugar level of salad dressings significantly decreased from 8.97 (2.34) g/100 g in 2017 to 1.58 (2.65) g/100 g in 2019 $(P=0.039)$. Compliance of mayonnaise and salad dressing fat contents with ISIRI limits increased from $42.9 \%$ and $84.6 \%$ in 2017 to $100 \%$ and $90.5 \%$ in 2019, respectively. None of the mayonnaise samples met the British Food Standards Agency salt target (maximum $1.25 \mathrm{~g} / 100 \mathrm{~g}$ ) in 2017 and 2019.
\end{abstract}

Conclusions: Reformulation of these products for reduction of salt and sugar content is necessary.

Keywords: mayonnaise; salad dressing; fat; salt; sugar

Citation: Khoshtinat K; Koohy-Kamaly P; Komeili-Fanood R; Sohrabvandi S; Khosravi-Darani K; Mohammadi M, et al. Comparative study of salt, total fat and sugar contents of mayonnaise and salad dressings from the Iranian market. East Mediterr Health J. 2021;27(5):452-458. https://doi.org/10.26719/ emhj.21.002

Received: 05/02/20; accepted: 07/05/20

Copyright (C) World Health Organization (WHO) 2021. Open Access. Some rights reserved. This work is available under the CC BY-NC-SA 3.0 IGO license (https://creativecommons.org/licenses/by-nc-sa/3.o/igo)

\section{Introduction}

Noncommunicable diseases (NCDs) such as cardiovascular diseases and diabetes are major concerns in industrialized countries (1) and were responsible for $82 \%$ of deaths in the Islamic Republic of Iran in 2016 (2). There is a link between dietary intake of fat, salt and sugar and NCDs (3-6). Trans and saturated fatty acids are a major cause of coronary heart disease (7). Excessive salt intake is related to risk of high blood pressure and cardiovascular diseases (5), which are responsible for $43 \%$ of mortality in the Islamic Republic of Iran (2).The World Health Organization (WHO) recommends a maximum daily intake of salt of $5 \mathrm{~g}$ for adults (8); however, the average intake in the Islamic Republic of Iran was 10 g/day in 2016 (2). The highest daily intake of sodium for women (3.9 g/day) in the Eastern Mediterranean Region was reported in the Islamic Republic of Iran (9). Consumption of foods containing high amounts of sugar increase the risk of dental caries (10). There is also a direct relationship between sugar intake in sweet drinks and diabetes $(3,4)$.
Nutritional status is one of the important causes of NCDs. Therefore, WHO implemented a global action plan for prevention of NCDs in 2004 and reduction of salt, sugar and saturated fatty acid levels, and elimination of trans fatty acids in commercial food products are emphasized. The global aims of 30\% reduction in salt intake by 2025 and halting the increase in diabetes and obesity were set by WHO (11). Eighty-three countries have salt-reduction strategies and 59 have aimed to reduce salt in commercial foods by establishing voluntary and mandatory targets, industry meetings, and reformulation. The Islamic Republic of Iran is one of the countries that is aiming to reduce salt intake by working with the food industry for reformulation of foods (12).

Mayonnaise, an oil-in-water emulsified semisolid food product, is prepared from vegetable oil, acidifying agent, egg yolk and optional components such as mustard and spices (13). Salt can contribute to product flavour and promote emulsion stability (14). It also helps to disperse the granules of egg yolk, which can improve surface 
active material. By neutralization of charges on proteins, salt allows them to adsorb to the existing layer on oil droplets. Too much salt can aggregate egg yolk proteins in aqueous phase by dehydrating them. Sugar can limit gelation of egg yolk, as well as being a flavouring agent (15). Compared to mayonnaise, which contains $60-80 \%$ oil, salad dressing has $<65 \%$ oil (16). Most previous studies have been done on the basis of the data collected from labelling of packaged mayonnaise and salad dressings $(17-23)$ and few have evaluated salt content $(24,25)$ total fat and sugar levels (25) and fatty acid composition (26). Based on a national programme, and in order to lower the incidence of NCDs, the Institute of Standards and Industrial Research of Iran (ISIRI) has revised the limits for sugar, fat and salt content.

The objectives of this study were to compare total fat, salt and sugar levels of commercial mayonnaise and salad dressing in the Islamic Republic of Iran in 2017 and 2019, and to monitor compliance with ISIRI standards.

\section{Methods}

\section{Study design}

This was a cross-sectional study and part of a national programme on monitoring the salt, fat, sugar, and saturated and trans fatty acid content in commercial and traditional food products in the Islamic Republic of Iran.

\section{Sample collection}

A total of 12 mayonnaises and reduced-fat mayonnaises and 47 salad dressing samples from 11 brands were collected from supermarkets in Tehran Province in 2017 and 2019. Salad dressing samples include French, thousand island, sandwich and other salad dressings (yoghurt, cheese and garlic, lemon and mild mustard dressings). The purchased samples were kept in the refrigerator and tested before the expiration date. All chemicals and solvents were of analytical grade and used without further purification. The salt, total fat and sugar levels of the samples were determined in triplicate according to the ISIRI methods $(13,27)$.

\section{Determination of salt}

For determination of salt content, $25 \mathrm{ml} 0.1 \mathrm{~N} \mathrm{AgNO}_{3}$ and $2 \mathrm{ml}$ concentrated nitric acid were added to $3 \mathrm{~g}$ of sample. The solution was made up to $100 \mathrm{ml}$ with distilled water and filtered. After addition of $2 \mathrm{ml} \mathrm{FeNH}_{4}\left(\mathrm{SO}_{4}\right)_{2} 12 \mathrm{H}_{2} \mathrm{O}$ to $50 \mathrm{ml}$ filtrate, titration by $\mathrm{NH}_{4} \mathrm{SCN}$ was conducted until the first appearance of a red-brown colour. Percentage of salt was calculated on the basis of the volume of $\mathrm{NH}_{4} \mathrm{SCN}$ used and the volume of $\mathrm{AgNO}_{3}(27)$.

\section{Determination of fat}

Total fat levels of the samples were determined by the Gerber method using butyrometer according to the Iranian national standards $(13,28)$.

\section{Determination of sugar}

For determination of total sugar, about $1 \mathrm{~g}$ active carbon was added to $26 \mathrm{~g}$ homogenized sample and the volume was made up to $100 \mathrm{ml}$ and filtered. Twenty-five millilitres of filtrate was transferred to a 100-ml round-bottom flask and $10 \mathrm{ml}$ concentrated hydrochloric acid and $10 \mathrm{ml}$ distilled water were added to the filtrate. For the hydrolysis step, the flask was rotated for 3 minutes and static for 7 minutes in a $60-70^{\circ} \mathrm{C}$ water bath. The flask was cooled in a beaker containing cold water; a few drops of phenolphthalein were added and the filtrate was neutralized by $\mathrm{NaOH}$. After recooling, the flask was made up to $100 \mathrm{ml}$ and neutralized filtrate was refiltered. While heating, the refiltrate was titrated using $5 \mathrm{ml}$ Fehling's A and $5 \mathrm{ml} \mathrm{Fe-}$ hling's B solutions and 1-2 ml methylene blue with a few pearls and distilled water (27).

The measured fat content was compared with the maximum fat content limits set by ISIRI for mayonnaise $(65 \mathrm{~g} / 100 \mathrm{~g})$, reduced-fat mayonnaise $(40-50 \mathrm{~g} / 100 \mathrm{~g})$ and salad dressings (36-56 g/100 g) (13). No standard limits were determined by ISIRI for salt and total sugar. Therefore, the measured salt contents were compared with the maximum salt targets for 2017 of the United Kingdom of Great Britain and Northern Ireland (UK) Food Standards Agency (FSA) for mayonnaise (1.25/100 g), reduced-fat mayonnaise $(1.7 \mathrm{~g} / 100 \mathrm{~g})$ and salad dressings $(1.5 \mathrm{~g} / 100 \mathrm{~g})(29)$ and the maximum sodium targets of the Federal Commission for Protection against Health Risks (COFEPRIS) for mayonnaise $(750 \mathrm{mg} / 100 \mathrm{~g})$ (21). After changing the units of the sodium target from $\mathrm{mg} / \mathrm{100} \mathrm{g}$ to $\mathrm{g} / 100 \mathrm{~g}$, they were converted to salt by multiplying by 2.54 in order to become comparable with the measured salt content of our study.

\section{Statistical analysis}

The data are shown as the mean (standard deviation) of triplicate determinations and analysed by independent sample $t$ test, one-way analysis of variance and one sample $t$ test using SPSS version 21 (SPSS Inc./IBM Corp., Chicago, IL, USA). $P \leq 0.05$ was considered significant.

\section{Results}

In the present study total fat, salt and sugar levels of 59 mayonnaise and salad dressing samples were evaluated in 2017 and 2019. In 2017, the samples included 7 mayonnaises and reduced-fat mayonnaises and 26 salad dressings. In 2019, 5 mayonnaises and reduced-fat mayonnaises and 21 salad dressings were tested.

\section{Mayonnaise}

The mean levels of total fat did not differ significantly between 2017 and 2019 in any of the mayonnaise samples (Table 1). The salt content of mayonnaise samples was significantly reduced from $2.03(0.3) \mathrm{g} / 100 \mathrm{~g}$ in 2017 to $1.61(0.12) \mathrm{g} / 100 \mathrm{~g}$ in $2019(P=0.031)$ (Table 2). As shown in Table 3, total sugar level of mayonnaise samples was significantly reduced from 5.97 (1.14) g/100 g in 2017 to $3.63(0.53) \mathrm{g} / 100 \mathrm{~g}$ in $2019(P=0.005)$ (Table 3$)$. 


\begin{tabular}{|c|c|c|c|c|c|c|c|}
\hline \multirow[t]{2}{*}{ Types } & \multicolumn{3}{|c|}{ Period 1 (2017) } & \multicolumn{3}{|c|}{ Period 2 (2019) } & \multirow[t]{2}{*}{$\mathbf{P}$} \\
\hline & No. & Mean (SD) & Range & No. & Mean (SD) & Range & \\
\hline Mayonnaise & 6 & $51.0(13.59)$ & $30-66$ & 4 & $58.36(14.12)$ & $41.44-70$ & 0.432 \\
\hline Reduced-fat mayonnaise & 1 & 55 & - & 1 & 40.24 & - & - \\
\hline All salad dressings & 26 & $40.38(8.84)$ & $21-53$ & 21 & $38.93(9.86)$ & $21-54$ & 0.596 \\
\hline Sandwich & 2 & $47(8.49)$ & $41-53$ & 2 & $47.5(9.19)$ & $41-54$ & 0.960 \\
\hline Thousand island & 8 & $36.76(9.36)$ & $24-51$ & 5 & $34.25(6.24)$ & $26-41$ & 0.912 \\
\hline French & 8 & $44(8.43$ & $29-53$ & 8 & $43.86(7.93)$ & $32-54$ & 0.515 \\
\hline Other salad dressings & 8 & $38.75(8.00$ & $21-46$ & 6 & $40.33(9.90)$ & $21-50$ & 0.587 \\
\hline
\end{tabular}

Replicates $=3$ (for all samples). SD = standard deviation.

\section{Salad dressings}

The total fat levels did not differ significantly between 2017 and 2019 in any of the salad dressing samples (Table 1). The salt content of salad dressings in 2019 [1.86 (0.39) g/100 g] did not differ significantly from that in 2017 [2.07 (0.37) g/100 g] (Table 2). Total sugar level of salad dressings was significantly reduced from 8.97 (2.34) $\mathrm{g} / 100 \mathrm{~g}$ in 2017 to $7.58(2.05) \mathrm{g} / 100 \mathrm{~g}$ in $2019(P=0.039)$ (Table 3). A similar significant reduction was observed for total sugar level of other salad dressings between 2017 and $2019(P=0.038)$.

\section{Compliance with standard limits}

Compliance of mayonnaise and salad dressing samples with ISIRI limits was $42.9 \%$ and $84.6 \%$ in 2017 , respectively, which increased to $100 \%$ and $90.5 \%$ in 2019 (Table 4).

As there is no ISIRI limit for the salt and total sugar contents of mayonnaise and salad dressing, we compared the salt content of our samples with the targets established by the UK FSA and COFEPRIS. Although none of the salt contents of the mayonnaise samples was compatible with the UK FSA targets (maximum $1.25 \mathrm{~g} / 100 \mathrm{~g}$ ), 33.3\% and $100 \%$ of the mayonnaise samples were compatible with COFEPRIS in 2017 and 2019, respectively (Table 5). For salad dressings, $11.5 \%$ and $23.8 \%$ of samples were in accordance with UK FSA salt targets (maximum $1.5 \mathrm{~g} /$ $100 \mathrm{~g}$ ) in 2017 and 2019, respectively.
Total fat levels of mayonnaise samples in 2019 [58.36 (14.12) g/100 g] and 2017 [51.0 (13.59) g/100 g] were not in accordance with the ISIRI limit ( $\geq 65 \mathrm{~g} / 100 \mathrm{~g}$ ). However, the difference between mean total fat and standard limits was not significant in $2017(P=0.053)$ and $2019(P=0.416)$. The salt content of mayonnaise samples in 2017 [2.03 (0.3) $\mathrm{g} / 100 \mathrm{~g}](P=0.001)$ and $2019[1.61(0.12) \mathrm{g} / 100 \mathrm{~g}](P=0.010)$ significantly exceeded the UK FSA target (maximum 1.25 $\mathrm{g} / 100 \mathrm{~g}$ ). Although mean salt content in 2017 was higher than the COFEPRIS target $(1.91 \mathrm{~g} / 100 \mathrm{~g})$, the difference was not significant $(P=0.382)$. The mean salt content in 2019 was significantly below the COFEPRIS target $(P=$ 0.017).

Total mean fat levels of salad dressing samples were in accordance with the ISIRI limit $(36-56 \mathrm{~g} / 100 \mathrm{~g})$ in 2017 [40.38 (8.84) g/100 g] [95\% confidence interval (CI): $36.81-43.95 \%]$ and 2019 [38.93 (9.86) g/100 g] (95\% CI: $34.44-43.42 \%)$. The mean salt content of salad dressing samples in 2017 [2.07 (0.37) g/100 g] and 2019 [1.86 (0.39) $\mathrm{g} / 100 \mathrm{~g}$ ] significantly exceeded the UK FSA target for 2017 (maximum $1.5 \mathrm{~g} / 100 \mathrm{~g})(P<0.001)$

\section{Discussion}

In the current study, total fat levels of mayonnaise samples in 2017 and 2019 were approximately twice those of mayonnaise samples $(30.76 \mathrm{~g} / 100 \mathrm{~g})$ in a study of 6 brands in Malaysia (25). In the current study, the salt content of

\begin{tabular}{|c|c|c|c|c|c|c|c|}
\hline \multirow[t]{2}{*}{ Type } & \multicolumn{3}{|c|}{ Period 1 (2017) } & \multicolumn{3}{|c|}{ Period 2 (2019) } & \multirow[t]{2}{*}{$\mathbf{P}$} \\
\hline & No. & Mean (SD) & Range & No. & Mean (SD) & Range & \\
\hline Mayonnaise & 6 & $2.03(0.30)$ & $1.67-2.46$ & 4 & $1.61(0.12)$ & $1.47-1.72$ & $0.031^{*}$ \\
\hline Reduced Fat Mayonnaise & 1 & 2 & - & 1 & 1.58 & - & - \\
\hline All Salad dressings & 26 & $2.07(0.36)$ & $1.34-2.47$ & 21 & $1.86(0.39)$ & $1.32-2.73$ & 0.069 \\
\hline Sandwich & 2 & $2.13(0.49)$ & $1.78-2.47$ & 2 & $1.58(0.01)$ & $1.57-1.58$ & 0.252 \\
\hline Thousand Island & 8 & $2.19(0.21)$ & $1.87-2.46$ & 5 & $1.95(0.35)$ & $1.51-2.35$ & 0.102 \\
\hline French & 8 & $2.32(0.29)$ & $1.78-2.69$ & 8 & $2.05(0.52)$ & $1.48-2.73$ & 0.191 \\
\hline Other salad dressings & 8 & $1.69(0.23)$ & $1.34-1.98$ & 6 & $1.65(0.13)$ & $1.32-1.95$ & 0.819 \\
\hline
\end{tabular}

${ }^{*}$ Significant difference $(P<0.05)$. Replicates $=3$ (for all samples). $S D=$ standard deviation. 


\begin{tabular}{|c|c|c|c|c|c|c|c|}
\hline \multirow[t]{2}{*}{ Type } & \multicolumn{3}{|c|}{ Period 1 (2017) } & \multicolumn{3}{|c|}{ Period 2 (2019) } & \multirow[t]{2}{*}{$\mathbf{P}$} \\
\hline & No. & Mean (SD) & Range & No. & Mean (SD) & Range & \\
\hline Mayonnaise & 6 & $5.97(1.14)$ & $4.38-7.80$ & 4 & $3.63(0.53)$ & $2.95-4.07$ & $0.005^{*}$ \\
\hline Reduced-fat mayonnaise & 1 & 6.14 & - & 1 & 4.20 & - & - \\
\hline All salad dressings & 26 & $8.97(2.34)$ & $4.57-15.94$ & 21 & $7.58(2.05)$ & $3.87-11.11$ & $0.039^{*}$ \\
\hline Sandwich & 2 & $6.65(2.93)$ & $4.57-8.72$ & 2 & $6.94(4.34)$ & $3.87-10.01$ & 0.944 \\
\hline Thousand island & 8 & $10.13(2.83)$ & $7.26-15.94$ & 5 & $8.92(2.740$ & $5.04-11.11$ & 0.431 \\
\hline French & 8 & $9.71(1.63)$ & $6.84-12.18$ & 8 & $7.89(1.86)$ & $4.50-10.33$ & 0.051 \\
\hline Other salad dressings & 8 & $7.63(1.36)$ & $5.41-9.87$ & 6 & $6.26(1.15)$ & $5.55-7.17$ & $0.038^{*}$ \\
\hline
\end{tabular}

${ }^{*}$ Significant difference $(P<0.05)$. Replicates $=3$ (for all samples). $S D=$ standard deviation.

mayonnaise samples in 2019 were significantly reduced in comparison with samples in 2017. In a study of salt content of foods over a 5-year period (2011-2016) in the Netherlands, the average salt content of 15 samples of 6 brands of emulsion-based sauces collected from local supermarkets was $8 \%$ lower compared to the average in 2011, but this reduction was not significant (24). The salt content of our mayonnaise samples in 2017 and 2019 was lower than the sodium content of mayonnaise (868.9 $\mathrm{mg} / 100 \mathrm{~g}$ or $2.21 \mathrm{~g} / 100 \mathrm{~g}$ salt) and reduced-fat mayonnaise (751.7 mg/100 g or 1.91 g/100 g salt) in Mexico (21) and higher than the sodium content of mayonnaise [603.6 (54.38) $\mathrm{mg} / 100 \mathrm{~g}$ or 1.53 (0.14) g/100 g salt) in Malaysia (25). In the current study, total sugar levels of mayonnaise samples in 2017 and 2019 were lower than those of mayonnaise samples [8.59 (1.20) g/100 g) in Malaysia (25).

In our study, total fat levels of salad dressing samples in 2017 and 2019 were higher than those of salad dressing samples $(29.85 \mathrm{~g} / 100 \mathrm{~g})$ obtained in 6 different mayonnaise and salad dressings brands in Malaysia (25). The salt content of salad dressing samples in 2017 and 2019 was lower than that salad dressing samples in Malaysia [848.67 (96.92) mg/100 g or 2.16 (0.25) g/100 g salt] (25) and Argentina (1493.4 mg/100 g or $3.79 \mathrm{~g} / 100$ g salt) (17). Moreover, in monitoring sodium content of processed food in Argentina, dressings were one of the categories within the sauces and spreads group with the highest median sodium content $(950 \mathrm{mg} / 100 \mathrm{~g}, 2.41 \mathrm{~g} / 100$ $\mathrm{g}$ salt). The total sugar levels of salad dressing samples in 2017 and 2019 were lower than those in salad dressing samples [15.47 (2.40) g/100 g] in Malaysia (25).

Although, the salt contents of none of the mayonnaise samples were compatible with the UK FSA targets (maximum $1.25 \mathrm{~g} / 100 \mathrm{~g}$ ), $33.3 \%$ and $100 \%$ of the samples were compatible with COFEPRIS in 2017 and 2019, respectively. Accordingly, the sodium levels of none of the mayonnaise samples in Mexico met the UK FSA targets. However, 59\% of the samples were in accordance with COFEPRIS (21). In a study conducted in Argentina based on the nutritional facts on the labels, none of the mayonnaise samples was above the regional sodium target for 2015 (1050 mg/100 g or $2.67 \mathrm{~g} / 100 \mathrm{~g}$ salt) and $97.1 \%$ were above the lower sodium target $(670 \mathrm{mg} / 100 \mathrm{~g}$ or $1.7 \mathrm{~g} / 100 \mathrm{~g}$ salt) (17). In recent years there has been a focus on producing reduced-fat and low-cholesterol mayonnaise and salad dressings in different ways, such as using fat substitutes or replacing fat with other natural ingredients $(30,31)$. Moreover, the impact of food taxation on reduction of sugar, salt and fat in commercial food products has been studied in several countries such as Denmark, United States of America, and Germany, confirming the WHO recommendations for governments using fiscal policies to promote healthy diets in the population (32-35).

\section{Conclusion}

Considering the increase in compliance with ISIRI limits for fat content between 2017 and 2019, the results of the current study seem satisfactory. Although there was

\begin{tabular}{lccccc}
\hline Table 4 Compliance of total fat levels in the studied mayonnaise and salad dressing samples with ISIRI limits & Period 2 (2019) \\
Type & No. & $\begin{array}{c}\text { Period 1 (2017) } \\
\text { Compliance (\%) }\end{array}$ & No. & Compliance (\%) & ISIRI limits (\%) \\
Mayonnaise & 6 & 33.33 & 4 & 100 & 100 \\
Reduced Fat Mayonnaise & 1 & 100 & 21 & 90.5 & $40-50$ \\
All salad dressings & 26 & 84.6 & 2 & 100 & $36-56$ \\
Sandwich & 2 & 100 & 5 & 50 & $36-56$ \\
Thousand Island & 8 & 75 & 8 & 100 & $36-56$ \\
French & 8 & 87.5 & 63.33 & $36-56$ \\
Other salad dressings & 8 & 87.5 & & $36-56$ \\
\hline
\end{tabular}

ISIRI = Institute of Standards and Industrial Research of Iran. 
Table 5 Percentages of compliance of the studied mayonnaise and salad dressing samples salt content with UK FSA and COFEPRIS targets

\begin{tabular}{lcccccccc} 
& \multicolumn{2}{c}{$\begin{array}{c}\text { Standard targets } \\
\text { UK FSA } \\
\text { Parget } \\
\text { P/100 g }\end{array}$} & $\begin{array}{c}\text { COFEPRIS } \\
\text { target }\end{array}$ & $\begin{array}{c}\text { No. } \\
\text { g/100 g }\end{array}$ & $\begin{array}{c}\text { Compliance } \\
\text { with UK } \\
\text { FSA (\%) }\end{array}$ & $\begin{array}{c}\text { Compliance } \\
\text { with } \\
\text { COFEPRIS (\%) }\end{array}$ & $\begin{array}{c}\text { No. } \\
\text { Compliance } \\
\text { with UK FSA } \\
\text { (\%) }\end{array}$ & $\begin{array}{c}\text { Compliance } \\
\text { with COFEPRIS } \\
(\%)\end{array}$ \\
Mayonnaise & $1.25(\max )$ & 1.91 & 6 & 0 & 33.3 & 4 & 0 & 100 \\
Reduced-fat mayonnaise & $1.7(\max )$ & - & 1 & 0 & - & 1 & 100 & - \\
Salad dressings & $1.5(\max )$ & - & 26 & 11.5 & & 21 & 23.8 & \\
\hline
\end{tabular}

COFEPRIS = Federal Commission for Protection against Health Risks; FSA = Food Standard Agency.

a significant reduction in salt and sugar contents of mayonnaise and sugar content of salad dressings from 2017 to 2019 , none of the mayonnaise samples met the UK FSA salt targets in either year. Therefore, reformulation of these products for salt reduction is necessary. It is recommended that standard limits for salt and sugar levels in mayonnaise and salad dressings be determined by ISIRI.

The current study was part of a national programme on monitoring nutritional risk factors for NCDs in Iranian food products, and a limited budget was allocated to the study of mayonnaise and salad dressings. The studied samples were well-known and highly consumed brands available in chain stores and supermarkets in Tehran, and did not include less-popular brands with low levels of production that were sold locally and not transported from other cities to Tehran. Therefore, our results are not completely representative of all mayonnaise and salad dressings retailed in the Iranian market. Unlike most other studies, which relied on food labelling, our results were based on chemical analysis of the samples, which was closer to the actual levels of the measured constituents. Future studies covering a wider range of brands and increased sample size will be useful. Moreover, the results of the current study may be used for updating the Iranian Food Composition Table. Generally, food product reformulation, introducing taxes on food and drinks containing high levels of sugar, salt or fat, setting standard limits, suitable methods of food labelling, and health education are effective ways of reducing the risk of NCDs.

\section{Acknowledgement}

The current study was part of a national project on monitoring salt, sugar, fat, and saturated and trans fatty acid contents in industrial and traditional food products in the Islamic Republic of Iran. The authors are grateful for the financial support for this project provided by the Food and Drug Administration of Iran, Ministry of Health and Medical Education, and the National Nutrition and Food Technology Research Institute, Shahid Beheshti University of Medical Sciences, Tehran, Islamic Republic of Iran.

Funding: None.

Competing interests: None declared.

\section{Étude comparative des teneurs en sel, en graisses totales et en sucre de la mayonnaise et des sauces pour salade du marché iranien}

\section{Résumé}

Contexte : L'apport alimentaire en graisses, en sel et en sucre est important pour la prévention des maladies non transmissibles; il est donc nécessaire d'évaluer ces constituants dans les aliments industriels emballés.

Objectifs : Comparer les niveaux de graisse, de sel et de sucre dans la mayonnaise et les sauces pour salade commercialisées en République islamique d'Iran en 2017 et 2019, et surveiller le respect des limites standard.

Méthodes: Les niveaux de graisse, de sel et de sucre dans 12 mayonnaises et 47 échantillons de sauces pour salade collectés sur un marché iranien ont été évalués selon l'Institut iranien des normes et de la recherche industrielle (ISIRI) et comparés entre 2017 et 2019.

Résultats : Nous avons déterminé la conformité aux limites ISIRI et aux autres objectifs standard. La teneur en sel des échantillons de mayonnaise a sensiblement diminué, passant de 2,03 g/100 g (écart type ; 0,3) en 2017 à $1,61 \mathrm{~g} / 100 \mathrm{~g}(0,12)$ en $2019(p=0,031)$. Le taux de sucre total des échantillons de mayonnaise a significativement diminué, de 5, $97 \mathrm{~g} / 100 \mathrm{~g}(1,14)$ en 2017 à 3,63 g/100 g (0,53) en $2019(p=0,005)$. Le taux de sucre total des sauces pour salade a considérablement baissé, de $8,97 \mathrm{~g} / 100 \mathrm{~g}(2,34)$ en 2017 à 1,58 g/100 g $(2,65)$ en 2019 ( $p=0,039)$. La conformité de la teneur en graisse de la mayonnaise et de la sauce pour salade aux limites ISIRI est passée 
de $42,9 \%$ et $84,6 \%$ en 2017 à $100 \%$ et $90,5 \%$ en 2019 , respectivement. Aucun des échantillons de mayonnaise n'a atteint l'objectif fixé par la British Food Standards Agency pour le sel (au maximum 1,25 g/100 g) en 2017 et 2019.

Conclusions : Il est nécessaire de modifier la formulation de ces produits pour réduire la teneur en sel et en sucre.

$$
\begin{aligned}
& \text { در اسة مقارنة لمحتويات المايونيز وصلصات السَلَطَات من الملح وإجمالي الدهون والسكر في السوق الإيرانية }
\end{aligned}
$$

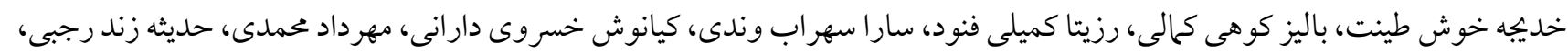

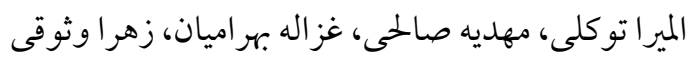

$$
\begin{aligned}
& \text { الخالاصة } \\
& \text { الخلفية: يُعتبر المدخول الغذائي من الدهون والملح والسكر مهاًً من أجل الوقاية من الأمراض غير السارية؛ ومن ثَمَّ، من الضروري تقييم هذه } \\
& \text { المكونات في الأغذية الصناعية المعبأة. }
\end{aligned}
$$

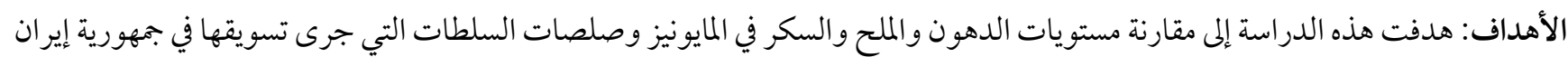

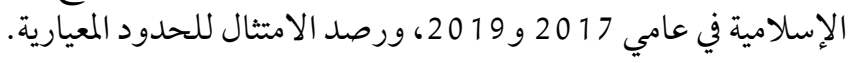

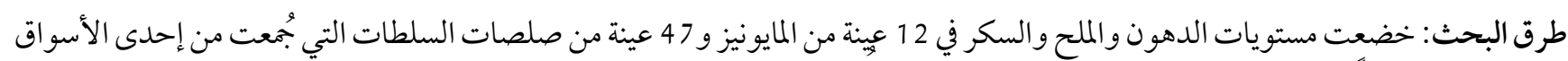

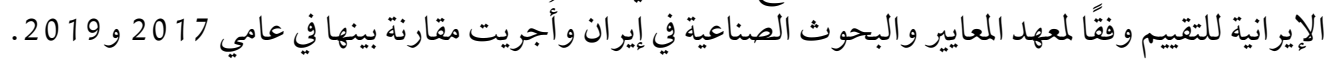

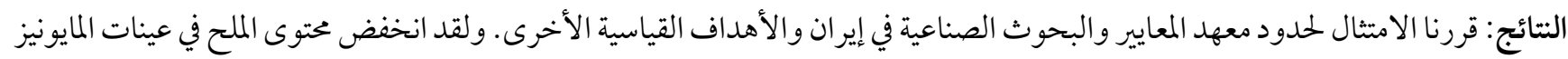

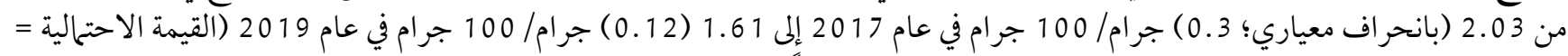

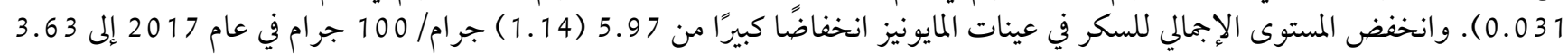

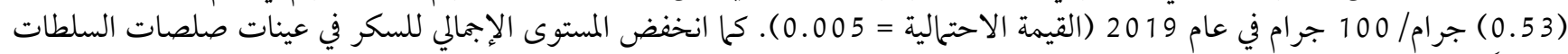

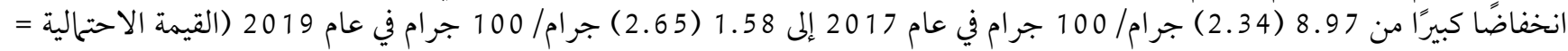

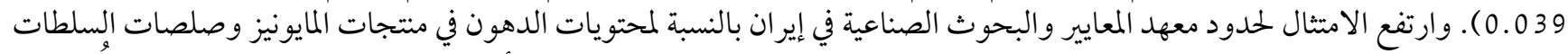

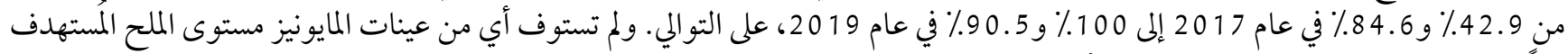

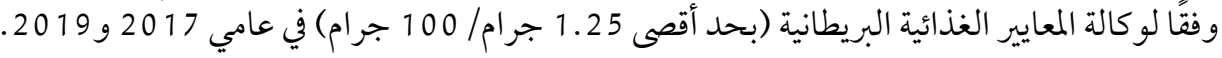

$$
\begin{aligned}
& \text { الاستنتاجات: من الضروري إعادة تركيب محتويات هذه المنتجات لتقليل محتوى الملح والسكر. }
\end{aligned}
$$

\section{References}

1. Caballero B, Rubinstein S. Environmental factors affecting nutritional status in urban areas of developing countries. Arch Latinoam Nutr. 1997 Jun;47(2 Suppl 1):3-8. PMID:965940

2. Noncommunicable diseases country profiles. Geneva: World Health Organization; 2018.

3. Yang Q, Zhang Z, Gregg EW, Flanders WD, Merritt R, Hu FB. Added sugar intake and cardiovascular diseases mortality among US adults. JAMA Intern Med. 2014 Apr; 174(4):516-24. https://doi.org/10.1001/jamainternmed.2013.13563 PMID:24493081

4. Malik VS, Popkin BM, Bray GA, Despres JP, Willett WC, Hu FB. Sugar-sweetened beverages and risk of metabolic syndrome and type 2 diabetes: a meta-analysis. Diabetes care. 2010Nov;33(11):2477-83. https://doi.org/10.2337/dc10-1079 PMID:20693348

5. Goncalves C, Abreu S, Padrao P, Pinho O, Graca P, Breda J, et al. Sodium and potassium urinary excretion and dietary intake: a cross-sectional analysis in adolescents. Food Nutr Res. 2016 Apr 11;60:29442. https://doi.org/10.3402/fnr.v60.29442 PMID:27072344

6. Booker CS, Mann JI. Trans fatty acids and cardiovascular health: translation of the evidence base. Nutr Metab Cardiovasc Dis. 2008 Jul;18(6):448-56. https://doi.org/10.1016/j.numecd.2008.02.005 PMID:18468872

7. Hu FB, Manson JE, Willett WC. Types of dietary fat and risk of coronary heart disease: a critical review. J. Am. Coll. Nutr. 2001 Feb;20(1):5-19. https://doi.org/10.1080/07315724.2001.10719008 PMID:11293467

8. Guideline: sodium intake for adults and children. Geneva: World Health Organization; 2012 (https://www.who.int/publications/i/item/9789241504836, accessed 5 January 2021).

9. Al Jawaldeh A, Rafii B, Nasreddine L. Salt intake reduction strategies in the Eastern Mediterranean Region. East Mediterr Health J. 2018 Feb 18;24(12):1172-80. https://doi.org/10.26719/emhj.18.006 PMID:30799557

10. Sheiham A, James WP. A new understanding of the relationship between sugars, dental caries and fluoride use: implications for limits on sugars consumption. Public Health nutr. 2014 Oct;17(10):2176-84. https://doi.org/10.1017/S136898001400113X PMID:24892213 
11. Global action plan for the prevention and control of noncommunicable diseases 2013-2020. Geneva: World Health Organization; 2013 (https://www.who.int/nmh/publications/ncd-action-plan/en/, accessed 5 January 2021).

12. Webster J, Trieu K, Dunford E, Hawkes C. Target salt 2025: a global overview of national programs to encourage the food industry to reduce salt in foods. Nutrients. 2014 Aug 21;6(8):3274-87. https://doi.org/10.3390/nu6083274 PMID:25195640

13. Mayonnaise and salad dressings - specifications and test methods. National Standard of Iran, No. 2454. Tehran: Institute of Standards and Industrial Research of Iran; 2014.

14. Ghorbani Gorji S, Smyth HE, Sharma M, Fitzgerald M. Lipid oxidation in mayonnaise and the role of natural antioxidants: a review. Trends Food Sci Technol. 2016 Oct;56:88-102. https://doi.org/10.1016/j.tifs.2016.08.002

15. Depree JA, Savage GP. Physical and flavour stability of mayonnaise. Trends Food Sci. Technol. 2001 May-Jun;12(5-6):157-63. https://doi.org/10.1016/S0924-2244(01)00079-6

16. Title 21 - food and drugs. Chapter I - Food and Drug AdministrationDepartment of Health and Human Services. Subchapter B - food for human consumption Part 169 - food dressings and flavorings. Subpart B - requirements for specific standardized food dressings and flavorings. Sec. 169.140 mayonnaise. Silver Spring, MD: U.S. Food \& Drug Administration; 2020 (https://www. accessdata.fda.gov/scripts/cdrh/cfdocs/cfcfr/cfrsearch.cfm?fr=169.140, accessed 5 January 2021).

17. Allemandi L, Tiscornia M, Guarnieri L, Castronuovo L, Martins E. Monitoring sodium content in processed foods in Argentina 2017-2018: compliance with national legislation and regional targets. Nutrients. 2019 Jun 28;11(7):1474. https://doi.org/10.3390/ nu11071474 PMID:31261665

18. Cardoso S, Pinho O, Moreira P, Pena MJ, Alves A, Moreira JL, et al. Salt content in pre-packaged foods available in Portuguese market. Food Control. 2019 Dec;106:106670. https://doi.org/10.1016/j.foodcont.2019.05.035

19. Tan M, He FJ, Ding J, Li Y, Zhang P, MacGregor GA. Salt content of sauces in the UK and China: cross-sectional surveys. BMJ Open. 2019;9(9):e025623. http://dx.doi.org/10.1136/bmjopen-2018-025623

20. Shahar S, You YX, Zainuddin NS, Michael V, Ambak R, Haron H, et al. Sodium content in sauces-a major contributor of sodium intake in Malaysia: a cross-sectional survey. BMJ Open. 2019;9:e025068. http://dx.doi.org/10.1136/bmjopen-2018-025068

21. Nieto C, Tolentino-Mayo L, Medina C, Monterrubio-Flores E, Denova-Gutiérrez E, Barquera S. Sodium content of processed foods available in the Mexican market. Nutrients. 2018 Dec 19;10(12):2008. https://doi.org/10.3390/nu10122008 PMID:30572568

22. Crino M, Sacks G, Dunford E, Trieu K, Webster J, Vandevijvere S, et al. Measuring the healthiness of the packaged food supply in Australia. Nutrients. 2018 May 31;10(6):702. https://doi.org/10.3390/nu10060702 PMID:29857517

23. Peters SAE, Dunford E, Ware LJ, Harris T, Walker A, Wicks M, et al. The sodium content of processed foods in South Africa during the introduction of mandatory sodium limits. Nutrients. 2017 Apr 20;9(4):404. https://doi.org/10.3390/nu9040404 PMID:28425938

24. Temme EHM, Hendriksen MAH, Milder IEJ, Toxopeus IB, Westenbrink S, Brants HAM, et al. Salt reductions in some foods in the Netherlands: monitoring of food composition and salt intake. Nutrients. 2017 Jul 22;9(7):791. https://doi.org/10.3390/ nu9070791 PMID:28737692

25. Abd Rashed A, Md Noh MF, Khalid NM, Ab Rahman NI, Tasirin A, Omar WSW, et al. The nutritional composition of mayonnaise and salad dressing in the Malaysian market. Sains Malays. 2017;46(1):139-47. http://dx.doi.org/10.17576/jsm-2017-4601-18

26. Nazari B, Asgary S, Sarrafzadegan N. Warning about fatty acid compositions in some Iranian mayonnaise salad dressings. Int J Prev Med. 2010 Spring;1(2):110-4. PMID:21566771

27. Pizza sauce - specifications and test methods. National Standard of Iran, No. 1024. Tehran: Institute of Standards and Industrial Research of Iran; 2007.

28. Milk Determination of fat content. National Standard of Iran, No. 384. Tehran: Institute of Standards and Industrial Research of Iran; 2009.

29. Salt reduction targets for 2017. London: Public Health England; 2017 (https://assets.publishing.service.gov.uk/government/uploads/system/uploads/attachment_data/file/604338/Salt_reduction_targets_for_2017.pdf, accessed 5 January 2021).

30. Mirzanajafi-Zanjani M, Yousefi M, Ehsani A. Challenges and approaches for production of a healthy and functional mayonnaise sauce. Food Sci Nutr. 2019;7(8):2471-84. https://doi.org/10.1002/fsn3.1132

31. Ma Z, Boye JI. Advances in the design and production of reduced-fat and reduced-cholesterol salad dressing and mayonnaise: a review. Food Bioproc Tech. 2013;6(3):648-70. https://doi.org/10.1007/s11947-012-1000-9

32. Falbe J, Thompson HR, Becker CM, Rojas N, McCulloch CE, Madsen KA. Impact of the Berkeley Excise Tax on sugar-sweetened beverage consumption. Am J Public Health Res. 2016 Oct;106(10):1865-71. https://doi.org/10.2105/AJPH.2016.303362 PMID:27552267

33. Garlichs D. National strategies for the reduction of sugar, fat and salt in food and beverages. Aktuel Ernahrungsmed. 2018;43:S37-41.

34. Smed S, Scarborough P, Rayner M, Jensen JD. The effects of the Danish saturated fat tax on food and nutrient intake and modelled health outcomes: an econometric and comparative risk assessment evaluation. Eur J Clin Nutr. 2016 Jun;70(6):681-6. https://doi.org/10.1038/ejcn.2016.6 PMID:27071513

35. Policy statement and recommended actions for lowering sugar intake and reducing prevalence of type 2 diabetes and obesity in the Eastern Mediterranean Region [website]. Geneva: World Health Organization; 2016 (http://www.emro.who.int/nutrition/ strategy/policy-statement-and-recommended-actions-for-lowering-sugar-intake-and-reducing-prevalence-of-type-2-diabetes-and-obesity-in-the-eastern-mediterranean-region.html, accessed 5 January 2021). 